\title{
THE SOCIAL SITUATION OF PARAPLEGICS AND TETRAPLEGICS IN THE NORTH OF PORTUGAL
}

\author{
By V. G. Gaspar, D.M. and R. Maia e Silva, D.M. \\ Serviço de Medicina Física e de Reabilitação, Hospital Geral de Santo António, Porto, \\ Portugal
}

Abstract. A study of the present social situation of 100 paraplegics and tetraplegics who received treatment in the Rehabilitation Service of the Hospital Geral de Santo Antonio, between I96I and 1979 has been carried out.

The information was obtained from clinical reports and from a questionnaire sent out in October I980, to I8I patients; I00 replies were received, from 78 men and 22 women. Most had traumatic spinal injuries (86 per cent).

FAMILY SITUATION-before the accident 59 per cent were married and 34 per cent single, and most of the latter were aged between I 6 and 30 years. In normal circumstances, people in these age groups would be more likely to change their status; but only three of our patients eventually married, which makes us believe that disablement had an influence. Divorce after disablement occurred in only two patients, which is not significant.

HOUSING CONDITIONS-40 per cent had no inside bathroom, 36 per cent had no piped water, 6 per cent no electricity. Forty-five per cent of their houses had stairs leading to the outside and in only 20 per cent have ramps been built. Only 30 per cent had adaptations to their home.

FINANCIAL POSITION-70 per cent lived exclusively on a pension or indemnity; and 9 per cent did not receive any kind of compensation. Eighty per cent of patients' earnings were below the I980 Portuguese Minimum National Wage (about $£ 70$ ).

RE-EMPLOYMENT-only I 8 of the men have an active professional life, six with the same job as before. The others changed to a different type of occupation compatible with their degree of disability, as most of them require to move by wheelchair. We strongly feel that age and the level of injury influenced the opportunities of re-employment, since most were aged between I 6 and 30 years at the time of their accident, and most had low thoracic or lumbo-sacral lesions (I5 cases). About 39 per cent of these patients earned more than the Minimum National Wage.

Summary of Paper read at the Meeting of the International Medical Society of Paraplegia, July, I98I. 